\title{
EVALUASI KARAKTERISTIK FISIK DAN UJI PERMEASI PADA FORMULA PATCH ASPIRIN MENGGUNAKAN KOMBINASI ETILSELULOSA DENGAN POLIVINILPIROLIDON
}

\author{
Arfiani Arifin ${ }^{1, *}$, Sartini², $^{2}$ Marianti \\ ${ }^{1}$ Jurusan Farmasi, FMIPA, Universitas Islam Makassar, Jalan Perintis Kemerdekaan KM.9 \\ No.29, Tamalanrea Indah, Tamalanrea, Kota Makassar, Sulawesi Selatan 90245 \\ ${ }^{2}$ Fakultas Farmasi, Universitas Hasanuddin, Jalan Perintis Kemerdekaan KM. 10, \\ Tamalanrea Indah, Tamalanrea, Tamalanrea Indah, Tamalanrea, Kota Makassar, \\ Sulawesi Selatan 90245 \\ *Email korespondensi: arfiani.arifin@gmail.com
}

\begin{abstract}
The aims of this research are to determine whether the polymer of ethylcellulose and PVP $K-30$, can form patch with good physical characteristics and effects on skin permeation in experimental animals. The performed examination concerned physical examination, such as organoleptic, moisture content, thickness, weight uniformity, and skin permeation test at experimental animal using rats and rabbit skin. The used comparison of ethylcellulose formulations and PVP K-30 were 7: 3 (F1), 8: 2 (F2) and 9: 1 (F3). Patch was created using casting solvent method or commonly known as solvent cast molding. The results of research showed that comparison of combined polymer ethylcellulose and PVP K-30 that produced a good physical characteristics was F2 (8: 2) and F3 (9: 1). Based on the examination towards permeation test using rat and rabbit skin membrane, it may be confirmed that the optimum formula was F3 (9:1) with the highest permeation value at rat $46.09 \%$ and rabbit $66,30 \%$.
\end{abstract}

Keywords: aspirin, patch, ethylcellulose and PVP K-30

\begin{abstract}
ABSTRAK
Penelitian ini bertujuan mengetahui kombinasi perbandingan polimer etilselulosa dan PVP K-30 yang menghasilkan karakteristik fisik baik dan pengaruhnya terhadap permeasi kulit pada hewan coba. Pengujian yang dilakukan meliputi pengujian fisik yaitu uji organoleptik, kadar air, ketebalan, dan keseragaman bobot, serta uji permeasi kulit pada hewan coba menggunakan membran kulit tikus dan kelinci. Perbandingan formulasi etilselulosa dan PVP K-30 yang digunakan adalah 7:3 (F1), 8:2 (F2) dan 9:1 (F3). Patch dibuat dengan menggunakan metode solvent casting atau dikenal metode cetak tuang. Hasil penelitian menunjukkan bahwa kombinasi perbandingan polimer etilselulosa dan PVP K-30 yang menghasilkan karakteristik fisik baik adalah F2 (8:2) dan F3 (9:1). Berdasarkan hasil pengujian terhadap uji permeasi menggunakan membran kulit tikus dan kelinci dapat disimpulkan bahwa formula optimum yaitu F3 (9:1) dengan nilai permeasi tertinggi pada tikus $46,09 \%$ dan kelinci $66,30 \%$.
\end{abstract}

Kata Kunci: aspirin, patch, etilselulosa, PVP K-30

DOI: https://doi.org/10.25026/jsk.v2i1.103 


\section{PENDAHULUAN}

Aspirin merupakan salah satu obat anti inflamasi non steroid (AINS) yang memiliki efek analgetik, antipiretik, anti inflamasi, dan antiplatelet dalam dosis rendah yang banyak digunakan untuk mencegah stroke berulang karena biayanya murah dan efek samping yang masih dapat diterima (1), (2). Aspirin juga efektif digunakan untuk profilaksis serangan stroke (3), (4), (5). Hal ini dapat terjadi karena aspirin bekerja melalui penghambatan siklooksigenase yang bertanggung jawab terhadap pembentukan tromboksan A2 yang merupakan aktivator agregasi platelet (3), (6).

Beberapa pendekatan formulasi aspirin telah dilakukan dalam berbagai sediaan. Formulasi aspirin dalam sediaan tablet konvensional sering menimbulkan efek iritasi di lambung. Selain itu, formulasi aspirin dalam bentuk tablet salut enterik menyebabkan penundaan absorpsi hingga sediaan mencapai usus halus (7). Alternatif penghantaran obat pada aspirin dapat dilakukan secara transdermal. Penghantaran obat secara transdermal memiliki banyak keuntungan seperti memberikan pelepasan obat yang terkontrol, menghindari metabolisme hepatik, menghindari pengaruh pencernaan, dan sebagainya. Mekanisme penghantaran obat secara transdermal adalah menghantarkan molekul obat melewati lapisan stratum corneum dalam kulit dengan berdifusi melalui lapisan lipid kulit (8).

Penelitian yang telah dilakukan oleh Ammar, dkk (2007) (9) mengenai desain transdermal pada aspirin sebagai antitrombotik menunjukkan bahwa formulasi transdermal mempengaruhi fungsi trombosit yang mengandung dosis yang rendah pada aspirin. Penelitian berikutnya dilakukan oleh Areeg, dkk (2009) (10) mengenai transdermal aspirin dengan metode matriks menggunakan eudragit dan polivinil alkohol (PVA) sebagai polimer memperlihatkan fluks secara signifikan lebih tinggi. Penelitian juga telah dilakukan oleh Banerjee, dkk (2012) (11) mengenai formulasi dan evaluasi transdermal patch pada aspirin dengan menggunakan Hydroxypropyl Methylcellulose (HPMC) dan Carboksimetilselulosa (CMC) sebagai polimer menyatakan bahwa difusi obat dalam tubuh dan tingkat permeasi berada di kisaran steady state sepanjang hari. Menurut Kandavilli (2002) (12) tentang teori penggunaan polimer sistem penghantaran obat secara transdermal menggunakan etil selulosa dan polivinipirolidon dapat mempercepat laju pelepasan obat dan penetrasi kulit. Berdasarkan hal tersebut, maka penelitian ini menggunakan polimer etil selulosa dan polivinipirolidon.

Sediaan transdermal patch tipe matriks digunakan sebagai desain sediaan aspirin. Hal ini dilakukan karena bentuk sediaan yang lebih kecil dan lebih tipis, lebih mudah, cepat, dan biaya relatif murah (13). Polimer yang digunakan sebagai pembawa pada tipe matriks ada dua jenis, yaitu polimer hidrofilik dan polimer hidrofobik. Penggunaan polimer hidrofilik seperti polivinilpirolidon (PVP) akan menyebabkan media disolusi mudah berpenetrasi ke dalam matriks, sehingga terjadi difusi bahan obat yang cepat. Penggunaan polimer hidrofobik seperti etil selulosa dapat memperlambat laju pelepasan obat, semakin tinggi konsentrasi etil selulosa yang digunakan, maka laju pelepasan obat makin lama. Pelepasan obat dapat lebih efektif jika dilakukan modifikasi dari sifat polimer dengan menggunakan campuran polimer, seperti kombinasi polivinilpirolidon dan etil selulosa. Pengaruh penambahan polivinilpirolidon ke dalam campuran etil selulosa menyebabkan terbentuknya poripori, sehingga menyebabkan laju pelepasannya konstan (12).

Beberapa penelitian mempelajari efek kombinasi polimer dalam membantu pelepasan obat. Salah satu penelitian 
tersebut oleh Hendradi dkk., (2010) (14) yang melaporkan kombinasi Etil Selulosa (EC) dan Polivinilipirolidon (PVP) menggunakan perbandingan 9:1, 7:3, dan 6:4 pada formulasi natrium diklofenak sistem penghantar transdermal patch. Variasi polimer tersebut dapat meningkatkan fluks pelepasan dan penetrasi natrium diklofenak dari matriks. Penggunaan Polietilenglikol (PEG) 400 sebagai plasticizer dengan kadar $36 \%$ menggunakan metode pembuatan matriks telah diperoleh perbandingan yang tepat untuk sediaan patch tipe matriks (15), (16). Berdasarkan hal tersebut, maka perlunya evaluasi karakteristik fisik dan uji permeasi pada formula patch aspirin kombinasi etilselulosa dengan polivinilpirolidon untuk mengetahui kombinasi perbandingan polimer etil selulosa dan PVP K-30 yang menghasilkan karakteristik fisik patch yang baik dan pengaruh kombinasi polimer tersebut terhadap uji permeasi pada membran kulit tikus dan kelinci.

\section{Metode Penelitian}

\section{Waktu dan Tempat}

Penelitian ini dilaksanakan mulai bulan Mei-Juli 2016 di Laboratorium Biofarmaka, Pusat Kegiatan Penelitian, Universitas Hasanuddin.

\section{Alat dan Bahan}

Alat yang digunakan adalah desikator, gelas kimia $\left(\right.$ Pyrex $\left.^{\circledR}\right)$, gelas ukur $\left(\right.$ Pyrex $\left.^{\circledR}\right)$, jangka sorong digital (absolut mitutoyo ${ }^{\circledR}$ ), magnetik stirer (Ika ${ }^{\circledR}$ RET basic), alat sel difusi, spektrofotometer $\left(\right.$ Shimadzu $\left.^{\circledR}\right)$, dan timbangan analitk (Sartorius ${ }^{\circledR}$ CP 224 S).

Bahan yang digunakan adalah Aspirin (PT. Kimia Farma Plant Bandung), Etil Selulosa (Pharmaceutical grade), PVP K-30 (Pharmaceutical grade), PEG 400 (Pharmaceutical grade), Mentol (Pharmaceutical grade), kloroform, aluminium foil.

\section{Prosedur Penelitian}

\section{Rancangan Formulasi Transdermal Patch}

Tabel 1. Rancangan formulasi transdermal patch

\begin{tabular}{lcccccc}
\hline \multirow{2}{*}{ Bahan } & \multicolumn{3}{c}{ Bobot per patch $(\mathrm{mg})$} & \multicolumn{3}{c}{ Bobot per batch/ 6 patch (mg) } \\
\cline { 2 - 7 } & $\mathrm{F} 1$ & $\mathrm{~F} 2$ & $\mathrm{~F} 3$ & $\mathrm{~F} 1$ & $\mathrm{~F} 2$ & $\mathrm{~F} 3$ \\
\hline Aspirin & 80 & 80 & 80 & 480 & 480 & 480 \\
Etil Selulosa & 150 & 172 & 194 & 903 & 1032 & 1161 \\
PVP K- 30 & 65 & 43 & 21 & 387 & 258 & 129 \\
PEG 400 & 180 & 180 & 180 & 1080 & 1080 & 1080 \\
Menthol & 25 & 25 & 25 & 150 & 150 & 150 \\
\hline
\end{tabular}

Keterangan:

F1 Perbandingan EC: PVP K-30 = 7:3

F2 Perbandingan EC: PVP K-30 $=8: 2$

F3 Perbandingan EC: PVP K-30 = 9:1

\section{Pembuatan sediaan patch aspirin} (11)

PVP K-30 dan etil selulosa ditimbang dan dilarutkan masing-masing dengan kloroform pada beker terpisah kemudian diaduk menggunakan magnetik stirrer. Menthol dengan Aspirin dilarutkan dengan kloroform dan diaduk menggunakan magnetik stirrer, sementara PEG 400 dilarutkan dengan kloroform pada beker terpisah. Larutan PVP yang telah larut dimasukkan ke dalam larutan 
etil selulosa kemudian diaduk hingga homogen. Larutan campuran Menthol dan Aspirin dimasukkan ke dalam larutan polimer serta larutan PEG 400 yang telah larut dicampurkan dan diaduk kembali hingga homogen dengan magnetik stirrer. Larutan yang telah tercampur dituang ke dalam cetakan kemudian dikeringkan pada suhu ruang selama 24 jam dengan mengunakan corong terbalik di atas cetakan. Patch setelah dikeringkan dimasukkan ke dalam desikator. Penelitian ini menggunakan tiga rancangan formula dengan tiga kali ulangan.

\section{Evaluasi Karakteristik Fisik}

\section{a. Pengujian Organoleptik}

Pengujian meliputi warna, bau, dan kondisi permukaan patch yang dihasilkan. Pengujian organoleptik ini dilakukan secara visual.

\section{b. Pengujian Ketebalan}

Uji ini dilakukan untuk mengetahui ketebalan pada setiap sediaan dengan menggunakan jangka sorong. Ketebalan patch diukur pada 5 titik berbeda dengan menggunakan jangka sorong. Persyaratan ketebalan patch yaitu tidak lebih dari 1 $\mathrm{mm}$ (17).

\section{c. Pengujian Bobot}

Uji ini dilakukan untuk mengetahui bobot sediaan patch. Sediaan patch diambil sebanyak 6 buah. Masing-masing sediaan ditimbang dan dilihat variasi bobotnya, bobot patch yang diharapkan sebesar $500 \mathrm{mg}$ (18).

\section{d. Pengujian kadar air}

Penetapan kadar air dilakukan menggunakan metode thermogravimetri. Sampel dikeringkan menggunakan oven pada suhu $105 \pm 5^{\circ} \mathrm{C}$ selama satu jam kemudian didinginkan pada desikator. Bobot sampel diukur kembali. Sampel dipanaskan kembali hingga bobot konstan.

$$
\begin{aligned}
& \% \text { kadar air }= \\
& \frac{\text { berat awal - berat akhir }}{\text { berat awal }} \times 100 \%
\end{aligned}
$$

\section{e. Penyiapan sel difusi}

Patch dimasukkan ke bagian tengah cakram bagian bawah, kemudian dipasang karet berwarna hitam di atas patch agar melekat erat dengan cakram bagian bawah. Cakram bagian atas dengan cakram bagian bawah digabungkan dengan menggunakan baut.

\section{f. Uji permeasi kulit}

Uji permeasi kulit dilakukan dengan menggunakan sel difusi. Kulit abdomen tikus dengan berat $170-180$ gram. Bulu bagian abdomen dicukur hatihati dengan menggunakan pencukur elektrik. Bagian dermis dibersihkan dengan aquadest untuk menghilangkan jaringan yang menempel atau pembuluh darah. Direndam dalam dapar fosfat $\mathrm{pH}$ 7,4 selama 1 jam sebelum dilakukan eksperimen dan diletakkan pada megnetik stirrer. Kompartemen cairan penerima pada alat sel difusi diisi dengan larutan dapar fosfat $\mathrm{pH} \mathrm{7,4}$ sebanyak $50 \mathrm{~mL}$. Sediaan transdermal patch Aspirin ditempatkan pada kompartemen donor yang dibatasi membran dari kulit tikus yang diletakkan pada alat sel difusi. Suhu kompartemen penerima diatur $37^{\circ} \mathrm{C}$. Pengambilan cuplikan $(3 \mathrm{~mL})$ dilakukan berturut-turut pada menit ke 30, 60, 90, $120,150,180,210,240,270,300,330$ dan 360. Volume cairan yang diambil segera digantikan dengan medium yang baru pada suhu yang sama. Cuplikan kemudian dianalisis menggunakan spektrofotometer UV-VIS pada panjang gelombang maksimumnya. Perlakuan yang sama dilakukan dengan membran kulit kelinci (19).

Perhitungan jumlah kumulatif aspirin dihitung berdasarkan zat aktif yang terpenetrasi per luas area kemudian dilanjutkan dengan perhitungan fluks aspirin berdasarkan hukum Fick 1. Profil kumulatif aspirin secara in vitro dapat 
dilihat dengan membuat kurva hubungan antara jumlah aspirin yang terpenetrasi terhadap waktu. Penentuan kecepatan penetrasi (fluks) aspirin sediaan patch berdasarkan kurva hubungan antara jumlah kumulatif aspirin yang terpenetrasi terhadap waktu (menit) dan dihitung regresi linearnya dengan menggunakan hukum Fick 1, slope dari persamaan regresi merupakan kecepatan penetrasi (fluks) aspirin dari basis.

\section{Analisis Data}

Uji analysis of variance (ANOVA) untuk melihat perbedaan bermakna antar formula pada sediaan aspirin patch transdermal tipe matriks. Apabila hasil yang diperoleh pada $\mathrm{F}$ hitung lebih besar dari $\mathrm{F}$ tabel menunjukkan adanya perbedaan bermakna, maka dilanjutkan dengan uji lanjut.

\section{HASIL DAN PEMBAHASAN}

Patch merupakan sistem pembawa yang mengandung lapisan adesif dan memberikan penghantaran senyawa obat pada sirkulasi sistemik dengan pelepasan terkontrol. Beberapa parameter dalam pemilihan zat aktif asprin adalah waktu paroh dibawah 10 jam, bobot molekul dibawa 400 serta memiliki bioavaibilitas yang rendah. Patch aspirin dibuat menggunakan metode solvent casting yang merupakan proses yang paling banyak digunakan dalam pembuatan sediaan patch. Patch dibuat dengan cara mencampur polimer (etil selulosa dan PVP) sebagai matriks terlebih dahulu kemudian ditambahkan bahan aktif (aspirin) ke dalamnya. Hal ini diharapkan agar matriks lapisan paling luar berfungsi untuk mencegah pengeluaran obat dan lapisan dalam berupa adhesive/perekat untuk mengontrol laju pelepasan obat (12).

Kenampakan fisik patch menggunakan perbandingan polimer EC dan PVP dapat dilihat pada gambar 1.

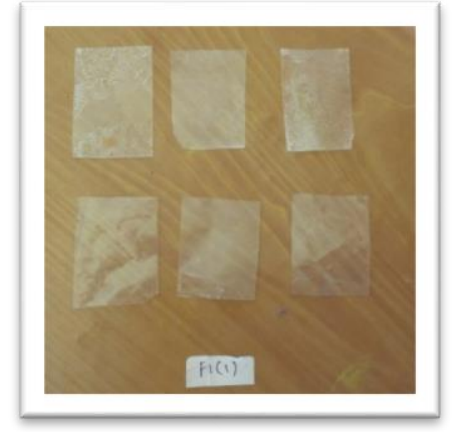

A

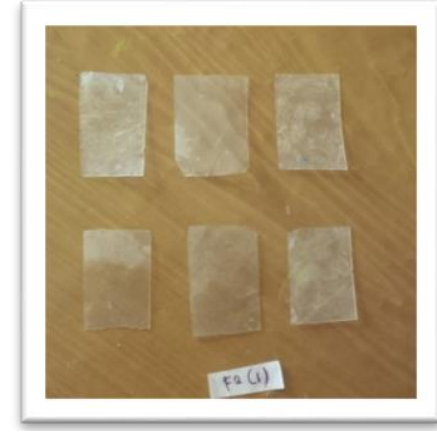

B

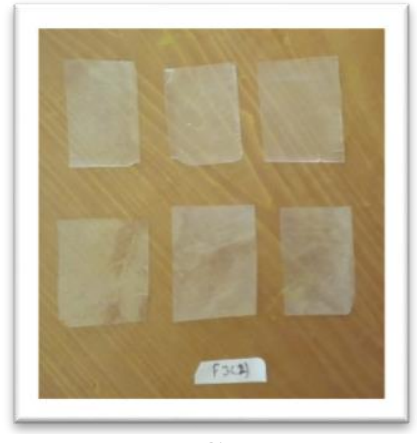

$\mathrm{C}$

Gambar 1. Patch aspirin menggunakan perbandingan polimer EC dan PVP; $\mathrm{A}=\mathrm{F} 1(7: 3), \mathrm{B}=\mathrm{F} 2(8: 2), \mathrm{C}=\mathrm{F} 3(9: 1)$

Tabel 2. Hasil evaluasi fisik sediaan patch aspirin

\begin{tabular}{clccc}
\hline Formula & \multicolumn{1}{c}{ Organoleptik } & $\begin{array}{c}\text { Kadar Air } \\
(\%)\end{array}$ & $\begin{array}{c}\text { Bobot } \\
(\text { gram })\end{array}$ & $\begin{array}{c}\text { Ketebalan } \\
(\mathrm{mm})\end{array}$ \\
\hline F1 & Agak basah, sedikit kasar & $3,40 \pm 0,48$ & $0,46 \pm 0,08$ & $0,45 \pm 0,01$ \\
F2 & Kering, halus & $3,35 \pm 2,40$ & $0,44 \pm 0,01$ & $0,43 \pm 0,01$ \\
F3 & Kering, halus & $3,30 \pm 0,95$ & $0,46 \pm 0,01$ & $0,42 \pm 0,01$ \\
\hline
\end{tabular}


Pengujian organoleptik pada penelitian ini bertujuan untuk mengetahui tampilan luar patch yang dihasilkan telah memenuhi persyaratan estetika atau tidak. Pengamatan ini dilakukan secara visual tanpa bantuan alat khusus dengan parameter melihat kondisi permukaan patch. Hasil yang didapatkan adalah patch F1 terlihat agak basah dan kasar diikuti patch F2 dan F3 memiliki kondisi permukaan yang sama yaitu kering dan halus. Hal ini dikarenakan kandungan dari PVP yang tinggi pada formula F1 yang bersifat higroskopis sehingga terlihat agak basah (20).

Pengujian kadar air dilakukan dengan mengukur bobot patch sebelum dan setelah dikeringkan. Pengujian ini untuk mengetahui kestabilan patch, selain itu juga mencegah kerapuhan dan menjaga patch dari kekeringan sehingga terlindung dari kontaminasi. Hasil yang diperoleh menunjukkan bahwa peningkatan kadar air pada ketiga formula disebabkan dengan bertambahnya jumlah polimer hidrofilik yaitu PVP. Hasil kadar air dari ketiga formula yang didapatkan sesuai dengan persyaratan kadar air patch yang baik yaitu memiliki rentang kurang dari $10 \%$ (19).

Pengujian keseragaman bobot dilakukan dengan menghitung bobot 6 buah patch pada masing-masing formula. Rata-rata bobot yang dihasilkan yaitu patch $\mathrm{F} 1$ adalah $0,46 \mathrm{~g}$, patch $\mathrm{F} 2$ adalah $0,44 \mathrm{~g}$, dan patch F3 adalah 0,46 g. Bobot patch yang dilakukan pada penelitian ini adalah $0,5 \mathrm{~g}$ dan hasil bobot yang diperoleh kurang dari 0,5 g. Hal ini diakibatkan karena patch yang dibuat menggunakan metode solvent casting atau penuangan sehingga menyebabkan kemungkinan larutan patch masih tertinggal pada beker gelas.

Pengujian ketebalan patch dilakukan untuk mengetahui ketebalan patch mengingat patch tipe matriks mempunyai bentuk sediaan yang lebih kecil dan lebih tipis (13). Hasil ketebalan yang diperoleh pada masing-masing formula sesuai dengan persyaratan ketebalan patch yaitu tidak lebih dari 1 $\mathrm{mm}$, apabila patch terlalu tebal maka akan sulit melepaskan zat aktif dari patch (17). Peningkatan jumlah etil selulosa dan penurunan jumlah PVP dapat meningkatkan ketebalan patch.

Pengujian permeasi obat dilakukan untuk mengetahui kemampuan permeasi obat dalam sediaan transdermal di kulit. Pengujian ini dilakukan menggunakan membran kulit tikus dan kelinci. Kulit tikus dan kelinci yang diambil bagian kulit abdomennya serta dibersihkan lalu dimasukkan ke dalam wadah kedap yang berisi es balok, setelah itu disimpan pada suhu $-80^{\circ} \mathrm{C}$. Sebelum digunakan, kulit tikus dan kelinci tersebut direndam dalam larutan dapar fosfat sebelum pengujian selama 1 jam.

Pengujian kemampuan permeasi menggunakan franz diffusion cell. Membran kulit tikus dan kelinci dipotong sebesar $3 \mathrm{~cm}^{2}$ disesuaikan dengan ukuran sel difusi dan volume dapar fosfat $\mathrm{pH} 7,4$ sebanyak $50 \mathrm{ml}$ yang dimasukkan ke dalam kompartemen cairan. Patch ditempelkan pada membran kulit tikus dan kelinci yang diletakkan pada alat sel difusi Franz. Jumlah cuplikan yang diambil pada kompartemen donor dianalogikan sebagai kondisi tempat sediaan transdermal yang ditempelkan yaitu di luar tubuh tepatnya pada kulit dan diganti dengan volume yang sama pada kompartemen reseptor yang dianalogikan sebagai kondisi di dalam tubuh setelah obat terpermeasi melewati kulit. Cuplikan yang telah diperoleh kemudian dianalisis dengan menggunakan spektrofotometer untuk memperoleh jumlah kadar aspirin yang terpermeasi tiap waktu tertentu.

Dari hasil permeasi menggunakan kulit tikus dan kelinci dapat dilihat dari jumlah kadar yang terpermeasi melalui membran kulit tikus dan kelinci nilai tertinggi dihasilkan oleh formula F3. Nilai tersebut menunjukkan bahwa semakin 
besar jumlah EC yang digunakan dan semakin sedikit jumlah PVP K-30 yang digunakan maka kemampuan permeasi zat aktif semakin tinggi (15), (16).

Uji permeasi kulit pada patch aspirin diketahui cukup menunjukkan permeasi aspirin pada membran kulit tikus dan kelinci. Pengujian untuk melihat profil permeasi secara keseluruhan dibutuhkan waktu uji permeasi yang lebih lama. Perlu diketahui waktu paruh aspirin sekitar 2 4,5 jam yang dimana pada penelitian ini dilakukan diatas pengambilan cuplikan sekitar 3 jam, dapat kita prediksikan dengan memasukkan persamaan regresi terhadap waktu untuk mengetahui kadar yang terpermeasi jika dibutuhkan waktu 4 jam.

Tabel 3. Jumlah kadar permeasi aspirin menggunakan membran tikus dan kelinci dari sediaan patch

\begin{tabular}{ccccc}
\hline Membran & Waktu & \multicolumn{3}{c}{ Jumlah Kadar (\%) } \\
\cline { 3 - 5 } Hewan & (Menit) & F1 & F2 & F3 \\
\hline \multirow{5}{*}{ Tikus } & 15 & $13,94 \pm 0,04$ & $26,44 \pm 0,55$ & $21,89 \pm 0,27$ \\
& 30 & $17,26 \pm 0,10$ & $29,03 \pm 0,26$ & $31,08 \pm 0,33$ \\
& 45 & $19,59 \pm 0,08$ & $33,54 \pm 0,20$ & $30,96 \pm 0,35$ \\
& 60 & $20,61 \pm 0,28$ & $37,50 \pm 0,43$ & $29,45 \pm 0,20$ \\
& 90 & $21,63 \pm 0,10$ & $39,31 \pm 0,41$ & $35,56 \pm 0,31$ \\
& 120 & $22,51 \pm 0,32$ & $43,39 \pm 0,41$ & $38,25 \pm 0,67$ \\
Kelinci & 150 & $23,73 \pm 0,14$ & $42,05 \pm 0,48$ & $42,89 \pm 0,07$ \\
& 180 & $25,65 \pm 0,6$ & $42,63 \pm 0,3$ & $46,09 \pm 0,3$ \\
\hline & 15 & $15,40 \pm 0,24$ & $22,79 \pm 0,17$ & $29,45 \pm 0,67$ \\
& 30 & $19,80 \pm 1,02$ & $24,36 \pm 0,17$ & $37,18 \pm 0,61$ \\
& 45 & $23,90 \pm 0,81$ & $28,67 \pm 0,73$ & $38,47 \pm 0,15$ \\
& 60 & $27,28 \pm 0,80$ & $36,57 \pm 0,20$ & $44,29 \pm 0,33$ \\
& 120 & $31,04 \pm 0,39$ & $41,77 \pm 0,78$ & $53,87 \pm 0,27$ \\
& 150 & $37,13 \pm 0,60$ & $44,74 \pm 0,38$ & $58,57 \pm 0,20$ \\
& 180 & $41,29 \pm 0,58$ & $52,92 \pm 0,56$ & $61,21 \pm 0,54$ \\
& & $43,24 \pm 0,06$ & $57,79 \pm 0,2$ & $66,30 \pm 0,2$ \\
\hline
\end{tabular}

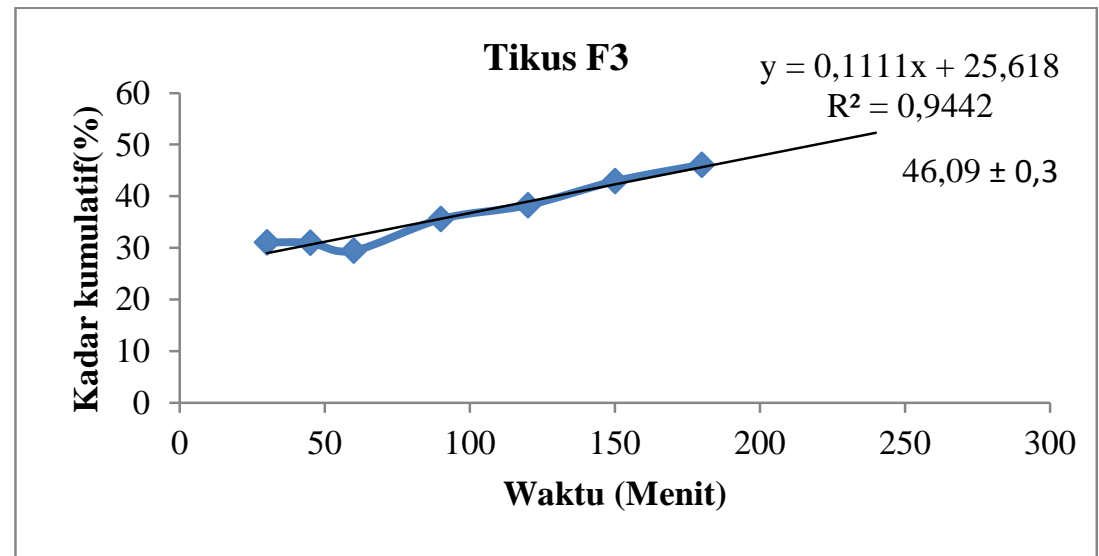

Gambar 2. Kurva hubungan anatara kadar terpermeasi dan waktu pada membran tikus F3 


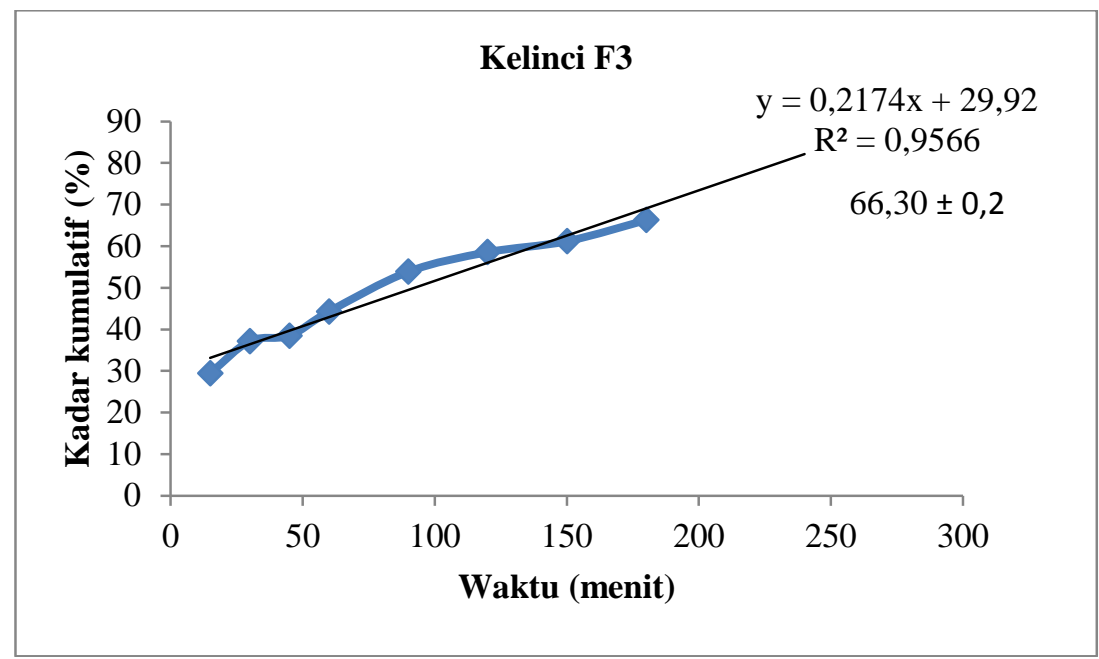

Gambar 3. Kurva hubungan anatara kadar terpermeasi dan waktu pada membran tikus F3

Perlu diketahui bahwa faktor lain yang mempengaruhi pengujian permeasi pada kulit dikenal dengan istilah absoprsi perkutan yang dimana proses masuknya obat dari luar kulit (epidermis) dalam hal ini sediaan patch yang dibuat, melintasi lapisan-lapisan kulit menuju posisi dibawah kulit yang diketahui mengandung lipid yang dimana menggunakan membran kulit tikus dan kelinci hingga masuknya molekul obat ke dalam sirkulasi sistemik dengan cara proses secara difusi pasif. Selain itu, faktor yang mempengaruhi yaitu kelarutan obat, koefisien partisi obat dalam polimer serta sifat fisika kimia polimer. Polimer memiliki pengaruh yang kuat terhadap difusi sebagai gerakan molekul (21). Kelarutan bahan aktif juga mempengaruhi lepasnya molekul obat dari polimer. Semakin larut suatu obat dalam sediaan, maka semakin mudah obat terpermeasi ke dalam kulit. Hasil menunjukkan bahwa formula F3 menunjukkan formula yang optimum. Faktor lainnya yaitu ketebalan patch pada formula F3 yang tipis diantara F1 dan F2 sehingga memudahkan proses permeasi yaitu molekul obat masuk ke dalam lapisan kulit membran kulit tikus dan kelinci.

Hasil pengolahan data menggunakan software SPSS 21 pada analisis regresi untuk uji Anova menunjukkan bahwa hasil persentase jumlah kadar permeasi aspirin menggunakan membran tikus dan kelinci pada setiap formula terdapat adanya perbedaan yang signifikan terhadap waktu, hal ini terlihat dari nilai signifikansi yang dihasilkan yaitu $0,01<$ 0,05 . Dilanjutkan pada tabel uji t terlihat bahwa ketiga variabel tersebut tidak ada yang berpengaruh, karena nilai signifikansi > 0,05. Hal ini menunjukkan tidak adanya perbedaan bermakna pada parameter perbandingan polimer. Namun, pada formula F3 menunjukkan nilai permeasi yang tinggi pada membran tikus dan kelinci.

\section{KESIMPULAN}

Berdasarkan hasil penelitian, maka dapat disimpulkan bahwa:

1. Kombinasi perbandingan polimer EC dan PVP K-30 dapat membentuk patch aspirin dengan karakteristik fisik. yang baik kombinasi perbandingan polimer etilselulosa dan PVP K-30 yang menghasilkan karakteristik fisik baik adalah F2 (8:2) dan F3 (9:1).

2. Berdasarkan hasil pengujian terhadap uji permeasi menggunakan membran kulit tikus dan kelinci, didapatkan formula optimum dengan kombinasi polimer EC dan PVP K-30 pada patch aspirin yaitu formula F3 (9:1) dengan nilai permeasi tertinggi pada membran tikus $46,09 \%$ dan kelinci 66,30\%. 
DAFTAR PUSTAKA

1. Huang Y, Li M, Li JY, Li M, Xia YP, Mao L, et al. The Efficacy and Adverse Reaction of Bleeding of Clopidogrel plus Aspirin as Compared to Aspirin Alone after Stroke or TIA: A Systematic Review. PLoS One. 2013;8(6).

2. Presley B. Penatalaksanaan Farmakologi Stroke Iskemik Akut. Bul Rasional [Internet]. 2013;12(1):6-8. Available from: http://repository.ubaya.ac.id/21378 /1/Rasional Vol 12 No 1.pdf

3. Awtry EH, Loscalzo J. Aspirin. Circulation. 2000;101:1206-18.

4. Lauer MS. Aspirin For Primary Prevention of Coronary Events. N Engl J Med [Internet]. 2002;346(19):1468-70. Available from:

http://jasoncartermd.com/resources /pdf/Aspirin for Primary Prevention of Coronary Events.pdf

5. Patrono C, Rocca B. Aspirin: Promise and resistance in the new millennium. Arterioscler Thromb Vasc Biol. 2008;28(3):25-33.

6. Kannan S, Manivannan R, Balasubramaniam A, Kumar NS. Formulation and Evaluation of Aspirin Delayed Release Tablet. Pharm Glob Int $\mathbf{J}$ Compr Pharm. 2010;1(4):1-3.

7. McEvoy GK, editor. AHFS Drug Information. Bethesda USA: American Society of Healt-System Pharmacist; 2002.

8. Amjad M, Ehtheshamuddin M, Chand S, Hanifa, Sabreesh M, Asia $\mathrm{R}$, et al. Formulation and Evaluation of Transdermal Patches of Atenolol. Adv Res Pharm Biol. 2011;1(2):109-19.

9. Ammar H, Ghorab M, El-Nahhas S, Kamel R. Evaluation of chemical penetration enhancers for transdermal delivery of aspirin. Asian J Pharm Sci [Internet]. 2007;2(3):96-105. Available from:
http://www.asianjps.com:8080/Jwe b_ajps/CN/article/downloadArticle File.do?attachType $=$ PDF\&id $=120$

10. Shamsher A, Charoo N, Kohli K, Pillai K, Rahman Z. Effect of Transdermally Delivered Aspirin on Blood Coagulation Parameters. Am J Biomed Sci [Internet]. 2010;2(2):129-41. Available from: http://www.nwpii.com/ajbms/pape rs/AJBMS_2010_2_04.pdf

11. Banerjee A, Harun al Rashid M, Chakraverty R, Dey S, Basak D, Biswas C. Preparation and evaluation of aspirin transdermal patch using HPMC. Int J Pharm Sci Rev Res. 2012;15(1):45-6.

12. Kandavilli S, Nair V, Panchagnula R. Polymers in Transdermal. Pharm Technol. 2002;(May):62-80.

13. Ansel HC. Pengantar Bentuk Sediaan Farmasi Edisi Keempat. Jakarta: UI Press; 1989.

14. Hendradi E, Isnaeni, Pujianti E, Fridayanti A. Optimasi Efektivitas Diklofenak. 2010;

15. Mukherjee B, Kanupriya, Mahapatra S, Das S, Patra B. Sorbitan monolaurate 20 as a potential skin permeation enhancer in transdermal patches. J Appl Res. 2005;5(1):96-108.

16. Ubaidulla U, Reddy MVS, Ruckmani K, Ahmad FJ, Khar RK. Transdermal Therapeutic System of Carvedilol: Effect of Hydrophilic and Hydrophobic Matrix on In Vitro and In Vivo Characteristics. AAPS PharmSciTech. 2007;8(1):2-8.

17. Shirsand SB, Ladhane GM, Prathap S, Prakash P. Design and evaluation of matrix type of transdermal patches of methotrexate. RGUHS J Pharm Sci. 2012;2(4):58-65.

18. Madhulatha, Naga R. Formulation and evaluation of ibuprofen transdermal patches. Int $\mathbf{J}$ Res pharmactical bio Med Sci. 2013;4(1):351-62. 
19. Kumar R, Philip A. Modified Transdermal Technologies: Breaking the Barriers of Drug Permeation via the Skin. Trop J Pharm Res [Internet]. 2007;6(1):633-44. Available from: http://www.ajol.info/index.php/tjpr /article/view/14641
20. Rowe R, Sheskey P, Quinn M. Handbook of Pharmaceutical Excipients. Handb Pharm excipients, Sixth Ed. 2009;549-53.

21. Garala KC, Shinde AJ, Shah PH. Formulation and in-vitro characterization of monolithic matrix transdermal systems using HPMC/Eudragit S 100 polymer blends. Int $\mathbf{J}$ Pharm Pharm Sci. 2009;1(SUPPL. 1):108-20. 